\title{
Historical Memory and Educational Privatization: A Portrait from Cambodia
}

\begin{abstract}
Will Brehm
Educational privatization has received increasing scholarly attention in recent decades. In much of this work, educational privatization is viewed as the outcomes of certain government policies or as the result of the influences of education businesses in school systems. This article presents a portrait of an educational entrepreneur in Cambodia to show how privatization has been enacted by individuals. The empirical data for this article was collected between February and May 2014 using classroom observations and in-depth interviews. The method of portraiture was employed to understand educational privatization through the perspective of the research subject while embracing the subjective nature of interpreting findings by the researcher. This article develops the literature on educational privatization by offering a detailed look at the way in which historical memory shapes the behaviour of individuals. This analysis shows how educational privatization is not only a process of government policy but also a social practice.
\end{abstract}

Keywords: Privatization, Cambodia, Portraiture, social theory $\backslash$

\section{Introduction}

In recent years, educational research has begun to challenge taken-for-granted spatial and temporal assumptions (e.g., Beech \& Larsen, 2014; Larsen \& Beech, 2014; Robertson, 2010). Space is no longer conceptualized as a neutral container where social phenomena occur but is rather viewed as constructed through social (and therefore political and economic) processes (Beech \& Artopoulos, 2015; see also Shields, 2013). Time has also been challenged: it is not only a linear process but also circular, iterative, and segmented (Rappleye \& Komatsu, 2016).

When put into practice, these "new" conceptualizations of space and time ${ }^{1}$ force educational researchers to re-conceptualize, re-draw, and re-think assumed scalar boundaries (Robertson, 2011), the implicit privileging of the nation-state as the standard unit of analysis (Dale \& Robertson, 2009), and even the very notion of comparison itself (e.g., Carney, 2009, p. 66). As Kenway (2015, p. 39), citing Marcus, observed about her multi-sited global ethnography of elite schools in seven countries, "de-facto comparisons develop because of "the fractured discontinuous plane of movement and discovery among sites as one maps an object of study and needs to posit logics of relationship, translation and association among these sites' (1998: 86)." Research, in other words, cannot assume bounded units or sites when working through new spatial and temporal conceptualizations, which include increased student/teacher mobility, the presence of non-state actors, and competing representations of history; rather, researchers must instead embrace "diverse connections, conjunctions, juxtapositions, and disjunctions" (Kenway, 2015, p. 47) to make sense of educational phenomena.

\footnotetext{
${ }^{1}$ These are not entirely new, as most of the researchers draw on rather "old" work from the 1970s and 1980s. Moreover, other academic fields like anthropology or sociology have long embraced these "alternative" ways of conceptualizing space and time.
} 
This article attempts to apply and subsequently extend some of new ways to think about space and time to the topic of educational privatization. Educational privatization has in fact already incorporated these new ideas in many respects. The use of social network theory, for instance, has been partially developed by analyzing privatization processes within global policymaking circles (e.g., Ball, 2012; Ball \& Junemann, 2012). One of the insights of seeing space as emergent and time as non-linear, however, is to focus the research gaze away from state and global policies and actors, instead focusing on the lived experiences and historical memory of individuals and their material objects inside systems of education (Beech \& Artopoulos, 2015, p. 8). A focus on individual actors has arguably been missing from research on educational privatization (Forsey, 2010, p. 240) and is precisely where ethnographic techniques can be useful. This article explores the way in which an individual actor socially produced educational privatization in Cambodia.

\section{Background and Context}

Cambodia is no stranger to crises. The crisis commonly associated with this small Southeast Asian nation is that of the genocidal regime of Democratic Kampuchea, typically referred to as Pol Pot's Khmer Rouge. Another crisis often overshadowed by, and certainly not as severe as the former, is that of the unprecedented international experiment in political and economic reforms in the early 1990s by the United Nations (Doyle, Johnstone \& Orr, 1997). This latter "crisis" (perhaps closer to a shock or transition) was managed by the United Nations Transitional Authority of Cambodia (UNTAC) and dramatically changed the physical as well as political, economic, and sociocultural landscapes of the country. Myriad forces drove these transformations, and the emergent consequences have shaped contemporary society.

One of the most dramatic areas of social change that marked the transition from a socialist to liberal state, which was the goal of UNTAC, was the pursuit of macroeconomic liberalization and privatization (commonly referred to as "neoliberalism"). The effort to liberalize the Cambodian economy formally began on May 6, 1994 under the Enhanced Structural Adjustment Facility (ESAF I) program supported by the International Monetary Fund (IMF) and later continued through the IMF ESAF II/Poverty Reduction Growth Facility program begun on October 22, 1999 (de Zamaroczy \& Sa, 2002 p. 5). These programs introduced laws to regulate banks, financial institutions, foreign exchange, and the value-added tax. On January 1, 2002, Cambodia officially accepted the IMF's general obligations of members outlined in Article VIII, which voluntarily bind national governments to keep current accounts free from restrictions and to maintain a unified exchange-rate system. The macroeconomic policy reforms signaled Cambodia's integration into the global economy of market capitalism after years of socialist experimentation.

Economic liberalization and privatization changed the education sector in important ways. The most notable change occurred in the higher education sector where private institutions began to proliferate in the 1990s after the national government adopted new laws that allowed non-public institutions to open. By 2013, there were twice as many private universities as public ones (Sen \& Ros, 2013). In addition, many public universities began admitting fee-paying students alongside scholarship students (Williams, Kitamura \& Zimmerman, 2012). This form of cost sharing is considered educational privatization because public universities rely on the revenue generated by user fees instead of government subsidies alone.

At the school level, the main privatization policy took the form of school-based management 
techniques, which were conceived as part of the process to decentralize educational authority to local actors. School based management gave communities control over the direction and funding of local schools, hence a transfer of power from a central ministry to local school communities. Comprised of a group of elected individuals in the community, School Support Committees (SSC), as they are called in Cambodia, were designed with the intention that residents could monitor and raise funds for the school in more effective ways than the national government. Shoraku (2008) situated SSCs inside the ideas of decentralization and cost-sharing and pointed out the policy that "prohibits schools from requiring parents to make private contributions" (p. 12). Instead, SSCs were intended to be ways through which community financing could thrive.

In actual practice, however, SSCs resulted not only in community but also in household financing for education, exactly opposite the policy highlighted by Shoraku (2008). Individual households were required to contribute money for their own children's education (i.e., household financing), not the education of the entire community (i.e., community financing). In this way, decentralization practices inside communities became a central process through which privatization took root in the school system, which has been found in other contexts (Verger, Novelli \& Altinyelken, 2012; Edwards \& Klees, 2012).

Although practices of privatization expanded in the education sector with the introduction of neoliberalism in the 1990s, there is in fact a long history of community financing to education. Pagodas have historically been places where community gather to raise money for road repair and educational development, goods that benefit everyone in nearby villages (WFDD, 2012). In the aftermath of the Khmer Rouge, communities were left to rebuild various social services (education, water distribution, road repair, etc.) with limited support from the national government. The Khmer Rouge regime had destroyed most state institutions (education, religious, and monetary, etc.), so the government that came to power in 1979 simply could not provide the social services demanded at the local level. An informant in Clayton's (2000) research who was involved in the initial organization of the Education Ministry stated as much: "We [the Ministry of Education] wanted the provinces to rely on themselves to open schools, even though no one had any books" (p. 111). Walford (2011, p. 410) labeled the process of communities developing schools when governments would not "reluctant privatization."

Eventually individual household financing usurped community financing. Contributions began to support the education of individual's own children, not the entire community. In 1997, the balance between household and government financing to education was roughly 80 percent by households and 20 percent by government (Bray, 1999, p. 47). The household contributions were spent on such items as school fees, uniforms, school improvement, schoolbooks, and school supplies and materials. Some of these costs, such as school improvement, could be considered community financing because all children in the community shared the item's benefit. Other costs, such as school uniforms or registration fees, could be considered household financing because only a household's children received the benefit. The household financing of education for self-interest is precisely where privatization emerges in the situated practices of individuals. This primarily occurred through private tutoring, whereby households (and not communities) paid teachers directly for additional help for their children (Bray \& Bunly, 2005).

The emergence of privatization within education during and after the UNTAC period can therefore be summed up along three general lines. First, the financing of education continued to rely on 
community (and household) contributions, something that dovetailed with a longer history of educational finance in the post-Khmer Rouge period. Second, the management of educational services was devolved from control by the central government to one overseen by local committees. The intention was that local communities could better meet local needs than the central ministry. Third, the provision of education, particularly at the tertiary level, would be opened to private actors. At the primary and secondary school level, this primarily took the form of private tutoring whereby mainstream teachers provided extra classes for a fee (Brehm, Silova \& Tuot, 2012).

This is not to say that since the 1990s the Cambodian Ministry of Education, Youth, and Sports (MoEYS) embraced an agenda of privatization at the expense of policies that promoted public education. In fact, MoEYS adopted various education policies that had aimed, at least in theory, to strength mainstream schools. Financing was the main way in which public schooling was advanced. This was done primarily through the Program Based (PB) budget, which was a policy that attempted to increase the funding and decision-making power inside local schools, and the elimination of enrollment fees. In turn, this policy aimed to reduce the financial burden of education on households.

The interesting aspect in the Cambodian context is that privatization emerged within local schools despite the efforts by the government to increase public funding. Additionally, there were no clear national polices advancing an agenda of privatization inside primary and secondary schools (other than school-based management) like there were in higher education. Yet, practices of privatization took root through government policies that intended to create systems of community financing and bolster public education management and governance. Households began to expect individual returns on their educational investment. These returns were most clearly found in private tutoring, which provided direct benefits to individual students (e.g., more time to study and prepare for examinations) and individual teachers (e.g., a supplement to their salaries). Another way in which privatization emerged was through non-governmental organizations (NGOs) that provided social services instead of state entities. Privatization as a result became pervasive across society and began to occur not as a process of policy creation and implementation but primarily as social practice constructed and justified by individuals. I now turn to studying one of those individuals, looking at his social practices and historical memory.

\section{Methods}

The empirical evidence in this article comes from an ethnographically-informed qualitative study of six individuals in one village outside of Siem Reap, Cambodia who enact educational privatization in diverse ways (Brehm, 2015). Taking heed of Burawoy's (1998) suggestion that researchers should "maximize variation within the field through constant comparison, searching for extreme cases in what is called 'theoretical' sampling" (p. 25), I worked with a group of actors - a public school teacher, parent, town elder, pagoda layman, government official, and NGO official $^{2}$ - who occupied central social positions that I learned were important during my time

\footnotetext{
${ }^{2}$ Perhaps the most notable absence from my group of participants is a student. A student was purposely not selected based on the assumption that most educational decisions regarding educational funding, curricular content, and teaching are made without student input.
} 
working in and researching the education system in Cambodia (since 2009).

Participants volunteered and were selected based on a pre-determined criteria: parents had to send their children to the local school and to private tutoring classes; teachers had to work in Preah Go and conduct private tutoring; the local government official had to work on education policy (broadly defined to include working with NGOs who provide educational aid) in Preah Go; the NGO school employee had to earn his salary from delivering educational services to children in Preah Go; the town elder had to be over 50 years old, have children, and have lived in the village since the end of the Khmer Rouge period (circa 1979); and the pagoda committee member had to be involved in pagoda and educational life in the commune (see Brehm. 2015, p. 100 for more details).

In this article, I report findings from the person who occupied the social position of an NGO official who started a school; or what can be called an educational entrepreneur named Mean Sokhem. ${ }^{3}$ The findings from Sokhem address issues around why he started a private school and the ways in which he draws on his historical memory to justify his actions. This micro level analysis of privatization opens the possibility to explore larger questions around "how sometimes contradictory socialising experiences can (co)inhabit the same body, how they establish themselves more or less durably in each body, and how they intervene at different moments of an individual's social life or biography" (Lahire, 2013, p. 112 cited in Trizzulla, Garcia-Bardidia \& Remy, 2016, p. 96).

I employ the method of "portraiture" (Lawrence-Lightfoot, 2005; see also Lahire, 2005) to make sense of Sokhem's actions, motivations, and historical memory for starting an education business. Portraiture "seek[s] to record and interpret the perspective and experience of [Sokhem], documenting [his] voices and [his] visions - [his] authority, knowledge, and wisdom (LawrenceLightfoot \& Davis, 1997, p. xv). The main tools of data collection for my study were in depth interviews and observations over two rounds of data collection. The first round took place in February 2014 and the second round took place in April/May 2014. The findings reported here are based on seven classroom observations conducted between February and May 2014 and five hours of in-depth interviews. During interviews, I allowed Sokhem to "tell [his] own story" (Burawoy, 1998, p. 13) and offer his own narrative (Mishler, 1986). By exploring the ways in which privatization manifest in and through one individual, the article presents a deeper understanding of the messy and mundane nature of educational privatization.

Portraiture is limited by the trustworthiness of Sokhem's narratives. How do I know I have not simply selected and reported fabricated stories? In order to prevent this possibility occurring as much as possible, I used a set of precautionary measures. First, I specifically selected Preah Go as the site of research because of my previous experience working in it. This gave me credibility and respect in the village, which might have helped reduce fabricated stories. Second, I designed the research to be extended in time (although, admittedly, not as long as Burawoy might have meant in his extended case study approach), which allowed me to visit Sokhem multiple times over the duration of field research. In effect, this provided time to analyze data between interviews, identifying possible areas of concern with the previous interview. In follow up interviews, I could interrogate past responses to fully verify them. Third, Sokhem was not the only source of

\footnotetext{
${ }^{3}$ The names of individuals and places have been changed.
} 
information for the construction of his portrait. I also used secondary interviews and observations of his context, which triangulated the trustworthiness of my findings as they emerged. In Sokhem's case, I also spoke with students in his school, other Khmer teachers, as well as international volunteers.

Various power imbalances during the research might have biased or skewed some of the findings as well. Based on Tuhiwai Smith's (1999) concept of "indigenous research," I recognize the limitations and power relations inherent in a white, male, middle-class, professional-class American researching individuals and communities in poverty-stricken Cambodia. To overcome this limitation, I worked through an NGO that has a history with the community under investigation. I also worked with Cambodian research assistants, with whom I had previous working experiences. The research assistants and the NGO built my credibility among the villagers, and hopefully limited the power imbalance that was inevitably present in this type of work.

Through Sokhem's portrait, I show how NGO schools emerged as a feature of educational privatization not because of a government policy per se, but rather because of the historical memories that have guided individual decision making. Sokhem's portrait provides insight into how privatization is socially produced and how the actions of individuals are partly governed by historical memory. Moreover, Sokhem's portrait shows how educational privatization takes forms beyond school based management and private tutoring, including forms of volunteer-tourism used to pay for educational services.

\section{Findings}

When I entered the school grounds of WfC, I came across a large field where students played. Looking beyond the litter, the school's grounds were quite picturesque with large coconut trees and rice fields encircling it. The school consisted of two buildings: the director's office and a building of five classrooms. The director's office stood alone, but there was a concrete foundation close by, for what, I had learned during my two weeks visiting the school, was to become a library.

The classrooms were in a long, rectangular building. The walls were concrete, as were the floors, and the windows in each classroom were covered in wood lattice painted red at the front and yellow at the back. There were shutters on each window and a large blue metal door for each room. The red metal roof and the absence of full walls between classrooms created an environment where noise traveled and bounced, causing a din when the five classrooms were full.

Inside each classroom, paintings of houses and animals, handprints and smiley faces covered the walls in bright colors. It looked as if children, adults, and foreigners were responsible for the paintings, as some were of higher quality than others and occasionally contained Chinese or Japanese script. There were also motivational sayings painted on the walls, reading, in English, for example, "aim high and try hard," "be the change you want to be in the world," and, most peculiarly, "stars can't shine without darkness." Given its placement inside a school, the latter phrase suggested that to be educated requires a relational understanding to those who are uneducated. On the outside of the classroom building, one side had the names of the school and director overlaying a giant elephant, a stereotypical symbol found in Southeast Asia; the other side showcased a painting of the earth with the names of various volunteer groups who support the 
school through donations or teaching. The school had a "global" feel to it and, in fact, donations from abroad were its primary source of income.

Started in 2009, WfC is an educational enterprise that provides 290 children with free English, computer, and dance lessons. It is not a formal school teaching a complete curriculum of Mathematics, Science, Khmer language, and History. Rather, it is a supplementary education enterprise - an NGO school - that caters to children who attend mainstream, government schooling but, for various reasons, attend additional classes at WfC.

WfC operates three shifts to accommodate the mainstream school schedules of most learners: Morning, afternoon, and evening. When children are not attending mainstream school, they have the option of attending classes at WfC. Older children or young adults who work during the day typically attend the evening sessions, while primary school-aged children (approximately 6 to 12 years of age, but sometimes older) attend either the morning or afternoon sessions. The students rotate sessions each month in line with their mainstream school shifts.

WfC is the brainchild of Mean Sokhem, who acts as the school's director, teacher, teacher-trainer, volunteer coordinator, and fundraiser. In his mid-thirties, Sokhem is a father of three children who moved to the Preah Go community specifically to open the school. At first the school charged students a small fee to cover operational costs (mainly to pay the salary of Sokhem), but since 2011 the school became a non-profit organization that has relied on donations from abroad and increased its teaching staff to nine. The school is Sokhem's main livelihood, but his salary fluctuates with donations. Salaries of other teachers, I learned, do not fluctuate, suggesting that Sokhem sometimes reduces his salary to pay the school's staff of nine.

On the first day I met Sokhem, he was waiting in his office. He had just finished a meeting with a group of foreigners who were either going to donate money or to send foreign volunteers to the school, or perhaps both. I was impressed with Sokhem's ability to manage such diverse activities; immediately after his time with me, he was going to teach an English class. Sokhem was very busy, but he always found time to sit and answer my questions. He also allowed me to observe the various classes being held.

Sokhem insisted I conduct each interview in English. As some of his quotes will reveal below, his English sentences can at times be riddled with mistakes, as is common for most second-language speakers. Nevertheless, I do not alter his sentences beyond adding words in brackets for clarity or the occasional footnote.

I was mainly interested in the emergence of NGO schools and their placement among existing institutions of education, namely public mainstream schooling and private tutoring. During the first interview, Sokhem differentiated between his non-formal school enterprise and the government public school system. While sitting on red-plastic chairs at a wooden table in his office, Sokhem explained to me the purpose of his school, loudly speaking over the noisy ceiling fan overhead:

Because right now, my role is also just education in English and also with a computer and also teaching the children how to dance and how to do any bracelets or something because I think that this one is just a skill not related to other education like [that offered by the] 
Ministry of Youth and Education [sic].

I then asked Sokhem why he focused on "skills."

Because you know like English is also the most important thing because English is also an international language so everyone works because, though I'm working, I just working through my English language so that causes English is also the most important. Every time we are interviewing we have to interview in English. Even though in Siem Reap, if you want to work in the restaurant and you want to get a high paid, we have to know how to speak English well, so English is all the most important thing. And one more [skill]: Computer. Computer is also the most important thing. If someone doesn't know how to use computer, it's very hard for them because when we are working they use computer to use in the office or something like that so computer is also one of important things.

Sokhem indicated that through the preparation of skills deemed valuable for a tourist-based economy (Siem Reap is home to the UNESCO world heritage site of Angkor Wat), he hoped to offer children a way out from a life of subsistence farming, which is the most common occupation among Preah Go residents. (The 2010 commune database indicates that eighty percent of households farm.) Although the Cambodian National Institute of Statistics (CNIS, 2010) reported Cambodia's unemployment rate is one of the lowest in the region, hovering at 1.6 percent in 2010, the reality for most people is a feeling of being trapped. They feel trapped in the sense of being dependent on subsistence farming, which does not offer a steady wage, depends on the vagaries of seasons, and has no clear path of upward mobility, but is nevertheless considered "employment" for accounting purposes. Indeed, the CNIS report found that 82.5 percent of workers nation-wide were in "vulnerable employment," meaning "unpaid family workers and own-account workers" (p. 25). In other words, most people rely on subsistence farming, which does not offer the protection of the types of jobs for which Sokhem was training students.

Sokhem, who grew up farming, understands the wish by many youth who dream of working in an air-conditioned building in the city center instead of picking and planting rice under the hot Cambodian sun. Skills in English and computer literacy, Sokhem believes, provide employment opportunities for the next generation of Cambodians - skills he did not learn from public school growing up.

Sokhem's desire to use education as a way out of poverty and his reliance on foreign donations and volunteers is a common feature in the privatization of education in Cambodia. Although this feature is not an extreme form of privatization where students pay fees for schooling (like in higher education), it nevertheless extends the understanding of public and private spaces of learning that have become blurred (Brehm, Silova \& Tuot, 2012). In Sokhem's school, the service is neither paid for by the State nor the students, but is rather passed on to international do-gooders. This type of mild privatization could be considered either "reluctant" (because public school does not offer everything parents demand) or "willful" (because private provision is of higher quality than public schools; Walford, 2011).

The rise of NGO schools shows a thoroughly private space of learning that students must navigate alongside a mainstream system that combines fee-free public schooling with fee-based private tutoring (Brehm, 2016a). Moreover, the rise of NGO schools highlights the displacement of 
household costs for education from local residents to global philanthropic networks who aid education in so-called "developing countries." The place of household financing of education, in other words, is stretched geographically because of NGO schools, reducing the burden on students to pay private fees.

In the sections that follow, I explore how household financing of education has created an avenue for the privatization of education and the struggles this creates for educators. The second subsection looks inside WfC to reveal a complex system of school financing from abroad and the emergence of privatization in the form of practices and social relations. By focusing on the pedagogical practices used at WfC in comparison to public, mainstream schooling as well as private tutoring classes, it becomes apparent that the history of household financing of education in which I situate WfC is, in fact, more personalized in Sokhem's perspective. WfC must be understood as an active response by Sokhem to alter educational practices he experienced in his childhood during mainstream public schooling. The third subsection explores the dilemma Sokhem faces by relying on foreign donations to fund WfC. It becomes apparent that Sokhem compromises some of his educational goals to meet the financial pressures of educating 290 children for free.

\section{Pedagogical practices influenced by personal history}

During my conversations with Sokhem, I probed into the pedagogy used at WfC. I was initially struck by the differences I noticed between the government school classes I had been observing, where reading out of a textbook was standard practice, and the classes at WfC where students were constantly at the board answering questions. Sokhem told me that there is a difference between the pedagogy of government school and that used in WfC:

You know I used to study at the government school, the difference like the government school they [do] not take care all the students... They don't take care because they just take care about the students if the students understand or don't understand. They don't take care about that. And they have to follow about the curriculum that the government gives to them but in here we are not follow any curriculum about the school. If example, we are teaching the lessons to the students but if [some] students still don't understand, we have to repeat the lessons again so we really need about the quality but we don't need about the quantity because sometimes, if they are failed or something like that, we have to let them to repeat. We have to repeat the lessons - repeat and repeat - and after that the students understand, we can go to another lesson.

In Sokhem's somewhat convoluted formulation, the government school teachers are bound by a national curriculum that limits the quality of learning because of the pressure to finish the curriculum within the schoolyear. In Sokhem's perspective, public school teachers are concerned mainly with completing the required tasks ("quantity" in Sokhem's words) without a concern for whether students understand the content or not ("quality" in Sokhem's words). By contrast, Sokhem emphasizes the concept of repetition, as I witnessed myself during the classroom observations. Although each Khmer teacher at WfC had unique pedagogical nuances, they all used Sokhem's preferred pedagogy of repetition. Exercises were repeated one after the other in order to drill various groups of words into the students' minds. When I asked Sokhem "where do you think [the practice of repetition] comes from?" he responded by saying, 
Mostly, we are doing this culture since we was a child so that causes if we don't do that maybe very hard for the students to control about their selves how to read the words because many Khmer cultures, they are very shy so we let them do that in order to make them more brave and more stronger-do not afraid for anyone.

Sokhem's answer of "culture" as a reason for repetition suggests there are standard practices in education that have endured through history. Indeed, the concept of repetition has a long history in Cambodia. For instance, Hansen (2007) considered rote learning a central feature in "the traditional form of monastic training...in Khmer monasteries" (p. 89). This "manuscript culture" style of learning included the recitation and rote memorization of Pali texts, which were often copied onto palm leaves by Khmer monks while studying in Siam (present day Thailand). Repetition and rote learning were precisely the pedagogical practices many development programs aimed to reform (Reimer, 2012; Bilodeau, et al., 1955).

Sokhem's emphasis on repetition and understanding, although reflecting the history of pedagogical practices, has a personal resonance in his own biography. It is his history that has caused him to employ specific practices at WfC, not a clear recognition of a cultural history that Reimer (2012) dates to $500 \mathrm{AD}$. Moreover, he perceived these practices as beneficial rather than detrimental to learning (as most academic publications assume).

Sokhem grew up in a rapidly changing educational environment in the post- Khmer Rouge period. He was born in 1981, two years after the collapse of Democratic Kampuchea, commonly called Pol Pot's Khmer Rouge. In those first 20 years of his life, he witnessed drastic changes as Cambodian society attempted to rebuild after decades of unrest, war, and auto/genocide. The most notable change Sokhem experienced was the transition from a Soviet-supported, Vietnamesebacked government in the 1980s to a free-market, Western-aided government in the 1990s (see Clayton, 2000).

At nine years old, Sokhem started school in 1990, and experienced extreme changes inside the public school system. He was one of the last groups of students to learn using textbooks that were translated by the Vietnamese. A picture of King Sihanouk and the Kingdom of Cambodia flag, which was introduced in 1993, would eventually replace the picture of Lenin that hung in his classrooms. Moreover, English would eventually replace the value of speaking Russian and Vietnamese.

As a child, Sokhem did not understand these larger, macro political-economic transitions. For him, what stuck out were everyday, situated experiences, which upon reflection he could evaluate during our conversations. The school Sokhem attended was dilapidated, like many rural schools at the time. "During that time," he recalled, "the room [was] very bad because the roof [was] leaking and making noises." He remembered that in primary school the teachers were absent so often that they would only finish half of the textbook, which was-and is - considered the curriculum. The teachers had been absent, he now understood, because at the time, with government salaries so low, most had to farm to survive. When I spoke with Sokhem, he told me of teachers who had asked students to help them farm during harvesting time. Since this was a way to impress a teacher, Sokhem often volunteered. He also remembered having to pay bribes and fees of all sorts simply to complete his education. In fact, Sokhem told me that he now believes the reason he did not pass the Grade 9 and Grade 12 national examinations on his first attempt was 
because he did not pay bribes to the examination proctors, who did not report cheating students who paid the bribes. During his second attempt on the examinations, he paid the proctors and passed (see Brehm, 2016b for more details on educational corruption in Cambodia).

When I asked Sokhem to reflect on how his childhood influenced his motivation to start his own educational enterprise, he said that his goal for WfC was to "change every activity of my old teachers." He remembered how teachers would teach "for one hour" and then let students play, sending them home at 11 o'clock. Some teachers would return home during the lunch break and drink rice wine, a common, cheap alcoholic beverage in rural parts of Cambodia. The drunken teachers would return to school to teach the afternoon shift and "make violence" with the students, "always angry with the children." Violence, unfortunately, was not exclusive to teachers who had had a liquid lunch; other teachers would make students hit their heads on the classroom door when an incorrect answer was given. In general, he believed teachers did not "care about the students even though they [got a] salary from the government." These were formative moments in Sokhem's image of teachers. "Because I see...the bad activities of the teachers," he recalled, "I [didn't] want to be a teacher [when I grew up]."

As life would have it, however, Sokhem did end up becoming a teacher. For him, the school he started and the teachers he hired were going to be different from the government school he remembered. The school would have "one mission [in regards to] education in the community....to help the poor people in the community," something the government had failed to do in his opinion. He instituted pedagogical practices that focused on student comprehension and teacher quality instead of the need to finish a textbook in a certain amount of time.

Repeating content became the primary pedagogy through which Sokhem achieved his goals. For him, repetition signified a departure from the history of educational practice in Cambodia, at least as he understood it. His lived experiences justified this memory. He even connected his actions to the long history of rote learning in Cambodian pagodas, not as a negative legacy as development organization and colonial scholars would have it, but as a positive legacy that should be emulated. The privatization of education in Cambodia thus emerged, in part, because of people like Mean Sokhem who were motivated to reach a level of educational quality that public school were perceived to be unable to achieve. The contemporary moment of educational privatization is, in this sense, a confluence of historical memory and an imagined future.

In addition to his focus on repetition as the key to educational success, earning money was not the main goal for Sokhem's venture or his teachers. He wanted to create a school that was different from the education system in which he had grown up. If his public school relied on household contributions, his endeavor would be different: a private venture that relies on non-local money.

\section{Volunteer-tourism and the business of NGO schools}

Although the purpose of WfC is based on a moral issue that emerged from Sokhem's personal history in education, practical issues that Sokhem manages require him to make comprises. The biggest issue facing Sokhem is funding. Sokhem has experimented with different ways to fund his school, from fees to donations to profit generating activities. When he originally started the school with a group of friends after graduating from university, he charged student fees. At first, Sokhem relied on household financing, common in Cambodia, whereby the user of the service pays a fee 
directly to the school. In these cases, the financing for the NGO school came from members of the local community, the households sending their children to Sokhem's first school. When this venture failed because too few students attended to make the business sustainable, he started a school on his own, which turned into WfC. He decided to make the school fee-free in 2011 after speaking with an international donor who convinced him to rely on foreign donations. (Giving up fees was a pre-condition for this donor to begin funding WfC.) This change in business model altered which households financed education in his NGO school from residents in Preah Go to international donors. No longer did users of Sokhem's educational service pay the fee but rather the fee was displaced to foreign households who felt compelled to donate money to support the school. In this way, the financing of the school was not located in the same place; school financing was globalized, but it was still not provided by the government. It was still private. Sokhem is currently experimenting with selling bracelets made by students to generate income, which is a movement away from household financing all together and instead entails a for-profit business model. In this financing model, Sokhem sells bracelets for money, which would then be used to fund WfC. No longer would foreign households give money for the education of Preah Go residents but rather would give money in exchange for a bracelet.

With each funding attempt, Sokhem has had to make comprises with his pedagogical goals. Charging fees limits access; making bracelets takes learning time away from students; and relying on volunteers alters his preferred pedagogical practices. This last compromise will be the focus of this subsection, as volunteers are Sokhem's main source of funding.

Sokhem relies on funding that comes in part from a growing trend in international development called "volunteer tourism" (Sin, 2010; Wearing, 2001). This is the practice where tourists not only sightsee while traveling abroad, but also spend time volunteering. In many cases, tourists-cumvolunteers spend large amounts of money to have international experiences, such as building water wells or teaching English classes, not only to help those who are less advantaged but also to improve their own resumes. Volunteers also provide WfC a level of legitimacy, as international people and institutions enter the village where WfC is located. More directly, the rise of volunteer tourism has altered the ways in which households finance education: instead of households in Preah Go paying for education, now households around the globe are paying for school operations.

Sokhem finds volunteers through volunteer tourist companies that locate potential volunteers worldwide and then sends profiles to Sokhem for him to select. Volunteers located this way pay the company for the experience. None of the money is passed on to WfC. He also partners with universities from abroad who send student volunteers to Cambodia on a yearly basis. Each university has its own system to fund these trips (sometimes students pay; other times they fundraise for their trips), but none of the money is given directly to WfC. Instead of charging a volunteer fee, Sokhem tries to convince volunteers of the financial hardship facing WfC once they are in the school. Of the hundreds of volunteers that have worked inside WfC since 2011, Sokhem has been able to establish a network of about 30 international donors. Most, to Sokhem's disappointment, are not regular donors, placing the financial health of the school in a yearly cycle of doubt. Nevertheless, these donors - and the companies or universities that sourced them hold enormous power inside WfC, as evidenced by the paintings on the walls. Without them the school could not function.

Often, and especially during the holiday season in December and January, foreign volunteers teach 
classes in place of the Khmer teachers. The Khmer teachers sit in the classes and act as translators for the volunteers. This is the locus of the compromise Sokhem must make: partly giving up on his goal of quality education to have potential donations from volunteers that are vital to the school's functioning.

Sokhem sees the value of the volunteers in two ways. The first value is educational: by having volunteer teachers, students can practice English with native (or at least fluent) speakers. Sokhem explained this to me one day while talking about volunteers generally.

You know this one is the main reason in here, we are focusing in English. So the most important thing like Khmer teachers sometimes it's very hard to let the children to speak in English in the class and sometimes when a foreign teacher comes to teach, it's the best way for the children to practice their English. Because if the foreigners didn't come here, maybe even though they just study English but maybe they know many, many words but they don't know how to speak. If the foreigner comes to study to teach them, the special thing they can practice English in the class and listening with foreigners are speaking in their class. And during they have a break, so the best thing the students and teachers can practice it with the foreigners.

During my time at WfC, however, most volunteers I met spoke English as a second language, just like the local Khmer teachers employed by the school. Therefore, the educational value of the volunteers is likely not as great as Sokhem suggested. ${ }^{4}$ The second value provided by the volunteers is the possibility of donations. During a volunteer's time at the school, Sokhem hopes to impress upon him or her of the school's desperate need for funding. He does this explicitly by posting a "wish list" of needed items outside his office door. He also solicits donations on Facebook, posting pictures of students who need bicycles or school materials. In return for these outward requests for money, volunteers are allowed to teach the children for however long they would like. When the volunteer returns home, it is his or her choice whether to provide donations to WfC. Sokhem estimates that one out of ten volunteers eventually send money to the school.

Sokhem acknowledged that volunteers pose certain problems in pursuit of quality education, as he perceives it. After Sokhem told me that volunteers can be problematic, I asked him why this was the case:

Because the most important thing like at the first time the volunteer when they come, sometimes they don't want to continue about their lessons because just talking and asking [with students] about their background and playing games and after that tomorrow comes, they [the volunteer] leave and another volunteer comes tomorrow, [and the students] asking the same... So that cause the most thing we just really need about the long volunteering comes but we are facing about if we didn't have volunteering like maybe we didn't have any sponsors. So but even though like volunteers coming for short or long, we are welcome

\footnotetext{
${ }^{4}$ For full disclosure, I did not witness volunteers teaching classes of higher-level English, which take place in the evenings. Such classes, if they had volunteers, could have provided students with time to converse with volunteer teachers who spoke English better than their Khmer counterparts. Such cases would achieve the value Sokhem explained to me.
} 
because sometimes, they can come for a short time but they give donations for the school.

Sokhem's compromise is thus between potential donations from short-term volunteers and classroom learning disruptions caused by their transient nature. Without short-term volunteers, which are most his volunteers, there would be "no school, no organization, no students." In other words, volunteers are vital to the survival of WfC, and Sokhem will compromise educational goals to keep his venture afloat.

\section{Discussion and Conclusion}

Sokhem and his school, WfC, illustrate part of the history and evolution of household financing of education, the trials and tribulations of attending mainstream public school during the 1990s, and the struggle between pedagogical goals and financial realities inside NGO schools. These insights add complexity to how and therefore why privatization emerged in education. Sokhem's portrait, moreover, reveals how the funding mechanisms of privatization are reconfigured and spread across the globe through volunteer-tourism.

The privatization of education, through Sokhem's portrait, is not an external force altering the educational landscape without the consent of agents. Rather, Sokhem's history suggests he was deeply aware of the troubles facing public education. Sokhem reflected on his history and decided to act by opening a school that taught valuable (in his perspective) skills for the economy. When issues of funding arose, Sokhem adapted to the situation, trying to find suitable and sustainable ways to fund his enterprise. Choosing to work with foreign volunteers might be perpetuating the volunteer tourist industry on one level, but the decision was also a departure from household financing of education as commonly understood and practiced through private tutoring. No longer would local households pay for education. By relying on international households to pay for education, Sokhem embraced a funding model where foreigners monopolized power inside the school. He was beholden to foreign volunteers who might become needed donors, allowing donor meetings to interrupt his classes and foreign volunteers to teach as they pleased.

Although it could be argued that Sokhem is simply bound by the discourse (and ideology) of decentralization or privatization (his school after all meets the goals of human capital development outlined by the government), a more nuanced view sees Sokhem and WfC as one part of the changing reality of education. Sokhem's moral imperative to provide educational experiences to children that he thought had been lacking in his childhood converged and furthered the household financing of education by opening additional spaces of education where children could learn. The effect of Sokhem's decision-not its original intention-was his school's contribution to the privatization of education, mainly in the form of new and different practices of learning and social relations between non-mainstream teachers and students.

In addition, Sokhem's portrait offers an insight into the contemporary phase of household financing of education. NGO schools funded by international donors have expanded the definition of "household" from a locally bounded group of residents near a public school, as originally conceived, to global households of international donors. International donors have far more say in the operations of WfC than either the residents of Preah Go or MoEYS. This is an important insight for policy makers to consider if and when privatization policies emerge: although off-setting costs, new financial arrangements necessarily result in new distributions of power. 
Sokhem's school adds additional layers of complexity to the practices of privatization. In the case presented, Sokhem understood his history and the history of Khmer culture to articulate a future utopia where all children could learn English and computer skills to a level public school was unable to achieve. The conception of past and present combined to inform his actions of privileging certain pedagogies (i.e., route learning) instead of others (i.e., finishing the curriculum quickly). The main pedagogy was the use of repetition, which Sokhem read in the history of education in Cambodia as a successful practice. Although he did not recognize the many failed attempts to halt the practice of repetition, he experienced poor teaching during his childhood, which he attributed to the lack of repetition. His individual experiences and perceptions of history helped drive educational privatization in a country that was focused on building the capacities of public school in its post-conflict era.

My goal in this article was to empirically show the production of a new space of education, one that although bounded geographically connects to globally circulating ideas and historical memory to justify agency. The new space can broadly be defined as educational privatization, although this article explored only a part of this admittedly complex phenomenon. By focusing on an individual's action and his understanding of his biography and Cambodian history that helped bring about the emergence of educational privatization in Cambodia, this article used an ethnographic approach that complements research studies on educational privatisation that have focused on policy. The findings showed that educational privatization is not only a process of policy making at the national or global levels but also a process of individual enactment. The findings of this study point to future directions in research on ethnography and education. The construction of shared meanings through historical memory is an important area of future work. Comparing shared meanings through a multi-sited ethnography (Marcus, 1995) would be one way to capture the similarities and differences of actually existing educational privatization worldwide. Is Sokhem's culturally informed view of education, for instance, shared by his students? Do other post-conflict societies reveal similar experiences? The answer to these questions cannot be found through policy research. An engagement with individuals inside schools is required.

\section{References}

Bilodeau, C., Pathammavong, S. and Lê, Q.H., (1955). Compulsory education in Cambodia, Laos, and Viet-Nam. Paris: UNESCO.

Ball, S. J., and C. Junemann. 2012. Networks, New Governance and Education. Chicago, IL: The Policy Press.

Ball, S.J. (2012). Global Education Inc.: New Policy Neoliberal Imaginary. New York: Routledge. Ball, S.J. (2010) Review of Hidden markets: The new education privatization, by Patricia Burch. British Journal of Sociology of Education, 31(2), 229-233.

Beech, J. and Artopoulos, A. (2015): Interpreting the circulation of educational discourse across space: searching for new vocabularies, Globalisation, Societies and Education.

Beech, J. and Larsen, M.A. (2014). Replacing old spatial empires of the mind: Rethinking space and place through network spatiality. European Education, 46(1), 75-94.

Bray, M. (1999). The private costs of public schooling: Household and community financing of primary education in Cambodia. Paris: UNESCO International Institute for Educational Planning (IIEP). 
Bray, M. and Bunly, S. (2005). Balancing the books: Household financing of basic education in Cambodia. Hong Kong: Comparative Education Research Centre, The University of Hong Kong and Washington D.C.: The World Bank.

Brehm, W.C., Silova, I. and Tuot, M. (2012). The Public-Private Education System in Cambodia: The impact and Implications of Complementary Tutoring. London: Open Society Institute.

Brehm, W. (2015). Enacting educational spaces: A landscape portrait of privatization in Cambodia. Unpublished PhD dissertation, University of Hong Kong.

Brehm, W.C. (2016a). "The contemporary landscape of education in Cambodia: Hybrid Spaces of the 'Public' and 'Private."' In K. Brickell and S. Springer Handbook of Contemporary Cambodia (pp. 271-282), New York: Routledge.

Brehm, W. C. (2016b). "The structures and agents enabling educational corruption in Cambodia:

Shadow education and the business of examinations." In Y. Kitamura, D.B. Edwards Jr., S. Chhinn, \& J. Williams. (Eds.). The political economy of schooling in Cambodia: Issues of equity and quality (pp. 99-119). New York: Palgrave MacMillan.

Burawoy, M. (1998). The extended case method. Sociological Theory, 16(1), 4-33.

Carney, S. (2009). Negotiating policy in an age of globalization: exploring educational 'policyscapes' in Denmark, Nepal and China. Comparative Education Review, 53(1), p. 63 88.

Clayton, T. (2000). Education and the politics of language: Hegemony and pragmatism in Cambodia, 1979-1989. Hong Kong: Comparative Education Research Centre, The University of Hong Kong.

CNIS [Cambodia National Institute of Statistics] (2010). Labour and social trends in Cambodia 2010. Phnom Penh: National Institute of Statistics, Ministry of Planning.

Dale, R and Robertson, S (2009). "Beyond methodological 'isms' in comparative education in an era of globalization." In R Cowen, AM Kazamias (Eds.), International handbook of comparative education (pp. 1113 - 1128). London: Springer.

de Zamaroczy, M. and Sa, S. (2002). Macroeconomic adjustment in a highly dollarized economy: The case of Cambodia. IMF Working paper WP/02/92.

Doyle, M.W., Johnstone, I., and Orr, R.C. (1997). Keeping the peace: Multidimensional UN operations in Cambodia and El Salvador. Cambridge: Cambridge University Press.

Edwards, D.B., Jr. and Klees, S.J. (2012). "Participation in international development and education governance." In (Eds.) A. Verger, M. Novelli and H.K. Altinyelken Global education policy and international development: New agendas, issues and policies (pp. 5576). New York: Bloomsbury.

Forsey, M. (2010) Review of Hidden markets: The new education privatization, by Patricia Burch. British Journal of Sociology of Education, 31(2), 236-241.

Geertz, C. (1973). The interpretation of cultures. New York: Basic Books.

Gomm, R., Hammersley, M, and Foster, P. (eds.) (2000) Case study method. London: Sage.

Hansen, A. R. (2007). How to behave: Buddhism and modernity in colonial Cambodia, 1860-1930. Honolulu: University of Hawai'i Press.

Kenway, J. (2015). "Ethnography 'is not what it used to be': Rethinking space, time, mobility, and multiplicity." In Bolling, S., Honig, M.S., Neumann, S., and Sele, C. (Eds). Multipluritrans in Educational Ethnography: Approaching the multimodality, plurality and translocality of educational realities (pp. 37-55). Bielefeld, Germany: Transcript Verlag

Lahire, B (2005) Portraits sociologiques: Dispositions et variations individuelles. Paris: Armand 
Colin.

Larsen, M.A. and Beech, J. (2014). Spatial theorizing in comparative and international education research. Comparative Education Review, 58(2), 191- 214.

Lawrence-Lightfoot, S. (2005). Reflections on portraiture. A dialogue between art and science. Qualitative Inquiry, 11(3), 3-15.

Lawrence-Lightfoot, S and Davis, J.H. (1997). The art and science of portraiture. San Francisco: Jossey-Bass.

Marcus, George (1995): Ethnography in/of the World System: The Emergence of Multi-Sited Ethnography. Annual Review of Anthropology, 24, 95-117.

Mishler, E.G. (1986). Research interviewing: Context and narrative. Cambridge: Harvard University Press.

Rappleye, J. and Komatsu, H. (2016). Living on Borrowed Time: rethinking temporality, self, nihilism, and schooling. Comparative Education.

Reimer, J.K. (2012) Local negotiation of globalized educational discourses: The case of child friendly schools in rural Cambodia. Unpublished $\mathrm{PhD}$ dissertation. The University of British Columbia (Vancouver).

Robertson, S.L. (2011) "The New Spatial Politics of (Re)Bordering and (Re)Ordering the StateEducation-Citizen Relation", International Review of Education, vol. 57, no. 3-4, pp. 277297.

Robertson, S. (2010). "'Spatializing' the sociology of education: Stand-points, entry-points, and vantage-points." In M.W, Apple, S.J. Ball, and L.A. Gandin (Eds.), The Routledge international handbook of the sociology of education (pp. 15-26). New York: Routledge.

Sen, V. and Ros, S. (2013). Anatomy of higher education governance in Cambodia. CDRI Working Paper Series No. 86. Phnom Penh: CDRI.

Shields, R. A. 2013. Globalization and international student mobility: A network analysis. Comparative Education Review, 57(4), 609-636.

Shoraku, A. (2008). Educational movement towards school-based management in East Asia: Cambodia, Indonesia and Thailand. Paper commissioned for the EFA Global Monitoring Report 2009, Overcoming Inequality: Why Governance Matters. Paris: UNESCO.

Sin, H.L. (2010). Who are we responsible to? Locals' tales of volunteer tourism. Geoforum, 41(6), 983-992.

Trizzulla, C., Garcia-Bardidia, R. and Remy, E. (2016). From Bourdieu to Lahire: Social determinism and pluralist consumer practices. Recherche et Applications en Marketing, 31(1), 85-102

Tuhiwai Smith, L. (1999). Decolonizing methodologies: Research and indigenous peoples. New York: Zed Book, Ltd.

Verger, A. Novelli, M., and Altinyelken, H.K. (2012). Global education policy and international development: New agendas, issues and policies. New York: Bloomsbury.

Walford, G. (2011). Low-fee private schools in England and in less economically developed countries. What can be learnt from a comparison? Compare, 41(3), 401-413.

Wearing, S. (2001). Volunteer tourism: Experiences that make a difference. New York: Cabi.

WFDD. (2012). Buddhism and development: Communities in Cambodia working as partners. Washington, D.C.: World Faiths Development Dialogue

Williams, J.H., Kitamura, Y., and Zimmerman T. (2012). Privatization and teacher education in Cambodia: Implications for equity. London: Open Society Foundations. 
